\title{
How Does Education Affect Political Trust?: An Analysis of Moderating Factors
}

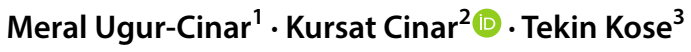

Accepted: 4 August 2020 / Published online: 9 August 2020

(c) Springer Nature B.V. 2020

\begin{abstract}
This article aims to understand the correlates of political trust by delving into the multiple interactive effects of education in democratic states throughout the world. It asks whether education raises political trust by increasing the stakes of the citizens in the system and whether education diminishes trust as a result of being abler to evaluate the existence of corruption in a given country. It also taps into how post-materialism as an individual-level factor affects this equation by activating critical judgments toward political institutions. The findings show that, indeed, the effect of education on political trust is very contextdependent. Political trust and education are positively correlated in more meritocratic countries and negatively correlated in the more corrupt ones. Post-material values, combined with educational attainment, tend to lower political trust to a certain extent yet this effect is surpassed by the presence or absence of meritocracy or political corruption. We also find that the effect of education on political trust becomes more pronounced as the level of education increases, with university graduates being the most susceptible to the effects of meritocracy and corruption on their trust levels.
\end{abstract}

Keywords Education · Political trust $\cdot$ Meritocracy $\cdot$ Corruption $\cdot$ Post-materialism

\section{Introduction}

This article examines the context-specific effects of education on political trust. It does so by looking at how educational attainment is moderated by post-materialism, meritocracy, and political corruption in determining trust levels of citizens toward political institutions. While there are a multitude of valuable studies in the area of political trust and its correlates, there are still interesting research questions that beg addressing in the education-political trust nexus. As Mayne and Hakhverdian (2016, p. 1) argue, the role of education in political trust is not sufficiently analyzed since education is usually included as a

Kursat Cinar

kursatc@metu.edu.tr

1 Department of Political Science and Public Administration, Bilkent University, Ankara, Turkey

2 Department of Political Science and Public Administration, Middle East Technical University, Ankara, Turkey

3 Department of Economics, TED University, Ankara, Turkey 
standard demographic control. Thus, cumulative evidence regarding the role of education is very limited and there is a lot to be done in that field (Mayne and Hakhverdian 2016, p. 1 and 24).

The findings of the extant literature on the effects of education on political trust go in different directions and are inconclusive (Hakhverdian and Mayne 2012, p. 739). There are diverging views on this issue. The first body of literature claims that the more people are educated, the more they will trust the political system. The underlying logic is that the more educated are more likely to benefit from political processes, for example presumably having better jobs and better life chances. They are also thought to better comprehend and appreciate the complexities of the democratic processes (Almond and Verba 1963; Stokes 1962, See Dalton 2005, p. 139). Educated citizens are believed to better understand and take part in politics and therefore develop more political trust (For a discussion of relevant literature see Bauer and Fatke 2014, p. 56). In this view, the educated mostly influence politics making use of the sophistication acquired through education while the less educated are alienated from politics lacking means similar to the ones acquired by the educated (Turper and Aarts 2017). This approach emphasizes the instrumental role education plays as education is believed to provide access to more privileged positions (Hooghe et al. 2015, p. 124).

An alternative view is that more education will lead to more critical citizens. It is argued that better-educated citizens are dissatisfied with the current state of politics (Dalton 2004). The reasoning behind this argument is that the better educated question political elites and traditional processes of representative democracy (Dalton 2005, p. 140). Overall, education as an explanatory variable has received scant attention and cumulative findings are sparse in individual level studies of political trust (Mayne and Hakhverdian 2016, p. 176).

The inconclusiveness of the body of research can be seen as a result of the samples selected (Mayne and Hakhverdian 2016). Depending on the sample (democratic-undemocratic, developed-underdeveloped etc.), studies do or do not find a strong significant correlation between education and political trust and the direction is either positive or negative (Mayne and Hakhverdian 2016). As this study will show, the direction of the relationship between education and political trust is not uniform across cases but depends on contextspecific factors as some studies have also pointed out earlier. For instance, Inglehart (2003, pp. 245-6) argues that while education affects respect for authority negatively in advanced industrial societies, it affects respect for authority positively in low-income societies. The reason for this difference is attributed by the author to the fact that post-material values are more activated in industrial societies compared to low-income societies. Inglehart believes that education serves as a proxy for economic security as those people who would obtain more education are more likely to come from a family that could provide them economic security, thus enabling them to be focused more on post-material values. As those holding post-material values are more likely to approach authority more critically according to Inglehart, citizens of advanced industrial countries who are more educated are also more likely to be critical toward authority. We will further delve into the interaction between education and post-material values below. Hakhverdian and Mayne (2012), on the other hand, show that trust and education are positively correlated in clean countries and negatively correlated in corrupt countries. The relationship between education and political trust should thus be approached context based and not in a uniform manner (see also Van Elsas 2015, p. 1158).

The few existing studies on education as an explanatory variable give us important clues about the role of education in determining political trust. Among the most notable are Hakhverdian and Mayne's studies (Hakhverdian and Mayne 2012; Mayne and Hakhverdian 
2016), which establish that "education has both a conditional and a conditioning effect on institutional trust" (Hakhverdian and Mayne 2012). They find that education has contextdependent effects on institutional trust such that the relationship is positive in clean societies and negative in corrupt ones. The reason, they find, is twofold: more educated citizens are better able to identify whether there is corruption or not and they are more easily troubled by the existence of corruption. This finding is important as it is one among the few studies that looks at the effects of education on trust. Yet, we want to go beyond the findings of that study in some regards. First of all, we want to see what competing mechanisms there are that operate in tandem with the existence or lack of corruption. Specifically, we want to understand how not just the level of corruption but also the level of meritocracy in a country or a person's post-materialist values have an influence over political trust. In some cases, a very meritocratic yet corrupt country may still garner the support of its educated citizens as they can see that their chances for upward mobility and economic prosperity are higher in the system due to their diplomas. In this article, we introduce other aspects to the research by asking not only whether and under what conditions citizens can become more critical of their institutions but also whether they can be so invested in the system due to their education that this investedness may override their propensity of being critical of their political institutions. Alternatively, we also test how post-materialist values relate to educational attainment to influence people's orientations toward political institutions.

In their study, Mayne and Hakhverdian look at 21 European democracies. Another recent study delving into the relationship between education and institutional trust argues that rational evaluation of trust is same across different levels of education (Van Elsas 2015). This study is based on a single country, the Netherlands, and thus is not able to tap into the effect of variation across cases in terms of issues such as corruption, meritocracy and levels of democracy as they are relatively constant for the case at hand. Our multilevel, cross-country study thus aims at contributing to this body of literature with a larger and more diverse sample of cases. Our sample extends the scope by including democratic countries regardless of their region, economic development, etc. In doing so, we allow for further variation in institutional operations of countries, thereby hoping to even better capture institutional constraints that countries put on the interaction between trust and education. Mayne and Hakhverdian themselves have maintained that in order to further understand the context-specific relationship between education and political trust, researchers should utilize "data from a much broader sample of countries than the small number of high-income consolidated democracies that currently dominates research in this area" (Mayne and Hakhverdian 2016, p. 191). Instead of using a split sample and taking democracy as constant, we include the level of electoral democracy as a control variable to see how the interaction between education and political trust changes as the level of democracy in a country changes. We aim to understand how citizens with the same level of educational attainment will react to polities with divergent levels of democratic quality. This will move education beyond a standard demographic control variable and help us understand its conditional effects under different political contexts. Differentiating countries with regard to their democratic quality and its interactive effects with education will also help us contribute to the existing literature, which lumps countries into predetermined, select groups (Western democracies, industrialized countries, new democracies etc.) (Anderson 1998; Mishler and Rose 2001; Zmerli and Newton 2008; Marien 2011; Hakhverdian and Mayne 2012; Hooghe and Marien 2013). These studies are illuminating to understand the determinants of political trust in those selected group of countries yet they fail to capture the contextual and conditional effects of education with other important political variables on political trust throughout the world. Putting countries in a continuum with regard to 
their quality of meritocratic government or the level of political corruption while also controlling for the effect of the quality of democracy will help us better explain under what circumstances education brings about positive or negative impact on political trust. In the following section, we offer multiple mechanisms through which education interacts with political trust.

\section{Theoretical Framework}

In this article, we argue that education's effect on political trust can be moderated differently by some micro- and macro-level variables. The interactive treatment of education as an explanatory variable will better shed light on effects of education on political trust and hence help resolve the contradictions about the relationship between education and political trust in the existing literature. Before doing so, we first need to clarify what is understood by political trust and identify its subcomponents. At a higher level, "trust" is a summary judgment "that the system is responsive and will do that is right even in the absence of constant scrutiny" (Miller and Listhaug 1990, p. 358). Specifically, political trust can be defined as the expectation that political institutions operate in line with the rule of law without continuous inspection (Marien 2011, p. 17). According to Miller and Listhaug (1990, p. 358), political trust reflects "evaluations of whether or not political authorities and institutions are performing in accordance with the normative expectations held by the public, which include that it be fair, equitable, honest, efficient, and responsive to society's needs." To this end, political trust integrates the concepts of impartiality, certainty, transparency, satisfaction with service delivery, political efficacy and participation (see also, Levi and Stoker 2000; McLaren 2012; Bouckaert and Van de Walle 2013).

As Norris (2003) indicates, objects of political trust can be abstract conceptualizations of political trust as well as specific political institutions. In this article, we focus on three major branches of national state institutions, i.e. the legislative, the executive, and the judiciary branches and investigate determinants of public trust vested in these key political institutions. Trust and confidence in major branches of state institutions are consequential for citizens' compliance with laws, greater policy innovation and positive risk taking, and heightened levels of legitimacy (Levi and Stoker 2000; Kelleher and Wolak 2007; McLaren 2012: Zmerli 2012; Bouckaert and Van de Walle 2013). These institutions and citizens' rapport with these political institutions lie at the very heart of contemporary democracies. Hence, we focus on these three specific institutions to better understand the people's relationship with core political institutions. Other scholars integrate additional supporting political institutions, such as the civil service, the police, local government into their analyses of political trust (see for instance, Mishler and Rose 2001; Anderson and Singer 2008; Hendriks 2009; Marien 2011; McLaren 2012; Hakhverdian and Mayne 2012; Hooghe and Marien 2013). While it can be empirically acceptable to build trust indices combining a volume of multiple trust indicators (assuming high correlation between these trust indicators), it can be theoretically wiser to stay focused on specific, core political institutions to better understand how citizens relate themselves to major national political institutions. It is hence our strategy to delve into the three major branches of national state institutions. We believe that although empirical results could have been similar if we had added additional trust indicators for other supportive political institutions, limiting ourselves with major political institutions would offer us a more refined analysis of political trust theoretically. 
We test the interactive, conditional effects of education on political trust based on three specific and separate mechanisms. First, we argue that education has an interactive effect with post-materialism. The relationship between education and political values and attitudes has been widely discussed in terms of whether there is a socialization and indoctrination mechanism at work or whether education merely serves as a proxy for more secure socio-economic status (Hooghe, Dassonneville and Marien 2015). As mentioned above, Inglehart sees the rise of post-material values with education through the lens of socio-economic security, attributing higher education to better socio-economic status during the formative years of an individual (Inglehart 1971, 1977, 1990), whereas Duch and Taylor (1993) and Davis (1996) argue that the relationship between education and post-material values can best be explained by the role of educational institutions in shaping value dominance in individuals.

Overall, the literature shows that education and post-materialism are linked but they do not always overlap. Duch and Taylor (1993), for instance, claim that it is not postmaterialism per se but rather democratic values that are increased through education. Moreover, Inglehart shows that it is only in post-industrial countries in which the more educated internalize more post-material values and that the more educated approach authority critically since it is only in these countries that the educated also experience socio-economic security in their formative years. Inglehart sees this as a ground for arguing that it is not education per se, but the presence of post-materialist values that explains declining deference to hierarchical institutions (Inglehart 2003, p. 245).

Post-materialism is believed to lead to "less deference to authority, more assertive styles of action, and higher expectations for the democratic process (Dalton 2005, see also Inglehart 1990, 1997; Dalton 2004). As they grow up in more socio-economically secure conditions, Inglehart (2003, p. 236) believes that those who hold post-material values are less inclined to idealize authority and are more critical and demanding visà-vis political institutions. Hence, to capture what we call the "critical effect" of education, we should take into account the conditional effect of education with post-materialism on political trust.

We hypothesize that,

H1 Holding the educational attainment level constant, citizens with post-materialist values (in contrast to materialist values) should have lower levels of political trust as the former have a more critical stance toward political institutions.

The second specific conditional effect of education is what we call the "enabling/ diploma effect" of education. Some scholars contend that educated citizens, thanks to their more developed skills, would take part in political processes more predominantly, benefit from these political interactions, and hence would have more vested interests and more trust in political institutions (Milbrath 1966; Richardson et al. 2001; Scheidegger and Staerkle 2011; Bauer and Fatke 2014). However, the underlying logic behind these mechanisms is that political institutions are meritocratic and would recruit the most appropriate citizens with the highest possible skills. Without such meritocratic institutional structure, education's "enabling effect" would wither away. Thus, we argue that educated citizens will have positive orientations toward political institutions if only they believe that these institutions are meritocratic and recruit them (or similar citizens with high skills) into political processes. In other words, we maintain that education's effect on political trust can be moderated by a country's level of meritocracy. Hence, we hypothesize that, 


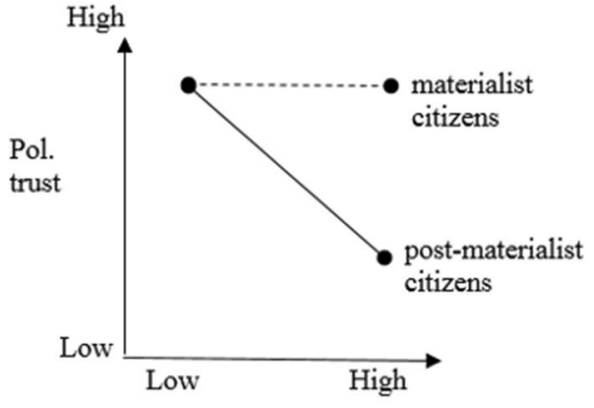

Education

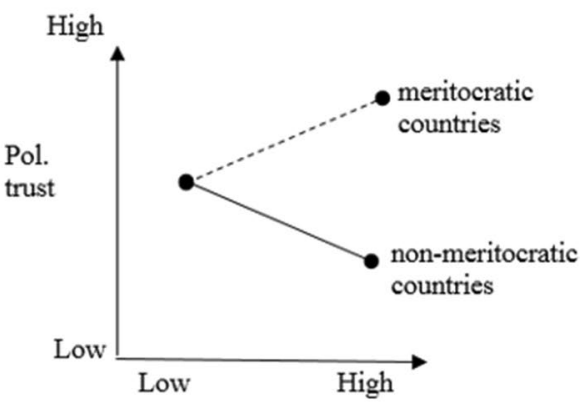

Education

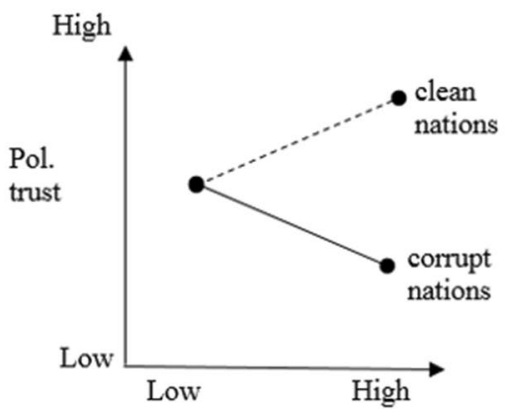

Education

Fig. 1 Contextual, moderated effects of education on political trust

H2 Holding educational attainment level constant, citizens living in more meritocratic countries should be more inclined to trust political institutions.

The third and the last interactive, conditional effect of education is what we call the "evaluative effect" of education. Citizens evaluate their countries' level of corruption, assess whether political institutions and actors aspire for the overall public good or line their own pockets (or their cronies) in corrupt, nepotistic and clientelistic networks, and thus develop trust judgments accordingly (Mishler and Rose 2001; Seligson 2002; Anderson and Tverdova 2003; Chang and Chu 2006; Hakhverdian and Mayne 2012). Hakhverdian and Mayne (2012) suggest that education has a conditional (as well as a conditioning) effect on political trust in linkage to corruption. To have theoretical and empirical consistency, we focus on the conditional effect of education on political trust in linkage to corruption. In other words, we test how education's impact on political trust can be moderated by the existence or lack of political corruption at the macro-level. We hypothesize that,

H3 Holding educational attainment level constant, citizens living in less corrupt nations should be more trusting in political institutions.

Figure 1 summarizes our conceptual model, in which we offer three alternative pathways through which education's effect on political trust can be moderated by micro- and macro-level factors. On the one hand, we argue that whether a person hold materialistic or 
post-materialistic attitudes towards the political system and its institutions can alter how educational attainment affects political trust. We maintain that it is only those educated citizens with post-materialist values who will hold critical stance toward political institutions. On the other hand, we also believe that contextual, macro-level factors may moderate education's effect on political trust. We contend that education's impact on political trust is conditional upon the existence or lack of meritocracy and/or political corruption at the country level, in which educated citizens in more meritocratic or cleaner societies will have higher levels of trust toward political institutions. In the following section, we provide the details of our methodology.

\section{Methodology}

To test the conditional, interactive effects of education on political trust, we mainly utilize the Wave 6 of the World Values Survey (2010-2014) for individual-level variables. To ensure maximum coverage of democratic countries, we include data from all countries in the WVS which either have a Polity IV score of 5 or higher ("full democracies" and "democracies" according to the Polity IV) or have a Freedom House status of "free" or "partly free" (in their respective survey year) (Polity IV Project 2019; Freedom House 2019). "The total number of democratic countries in our analysis is 40 (see "Appendix 1" for survey years and the number of participants). The selection of our sample ensures a diverse body of democratic nations throughout the world, which transcends regional foci of many scholarly works on political trust. Additionally, we make use of multiple international databases for our country-level variables such as meritocracy, political corruption (for all of our variables' descriptions and data sources as well as descriptive statistics, see "Appendices 2 and 3"). All in all, we ensure maximum coverage of democratic countries throughout the world based on the WVS results and supporting databases. ${ }^{2}$

\subsection{The Dependent Variable}

Our trust variable, which is the dependent variable of this study, is composed of trust indicators on three main branches of the state. Namely, it covers trust indicators on the legislative (parliament), the executive (government), and the judiciary (justice system). The

\footnotetext{
138 countries satisfy both criteria of Polity IV and Freedom House status (Polity IV Project 2019; Freedom House 2019). The only two countries that have a contradictory status in our Polity IV and Freedom House classification are Nigeria and Singapore, which have "partly free" status in the Freedom House Index whereas they have a Polity score lower than 5 (Nigeria has a Polity score of 4 for their survey year 2011 and Singapore -2 for their survey year 2012). Including or excluding these two countries does not change our substantive findings. Hence, to ensure maximum coverage, we have decided to include these two countries (results without these countries are also available upon request).

2 In our analysis, we exclude authoritarian countries due to their high level of "preference falsification" (Rose 2007; Darden and Grzymala-Busse 2006). Preference falsification refers to the situation in which people deliberately misrepresent their genuine views under perceived social and political pressures (Kuran 1997; Wedeen 1999). Jiang and Yang (2016) show, for instance, that ordinary citizens in authoritarian states are indeed very hesitant to reveal their opinions, especially when discussing important political issues. In a study such as this one, in which public opinion data on governmental and state trust is investigated, there is a high likelihood that people in authoritarian regimes will deliberately conceal their views and make the results spurious. Thus, we refrain from including authoritarian regimes.
} 
corresponding survey question of WVS is framed as follows: "I am going to name a number of organizations. For each one, could you tell me how much confidence you have in them: is it a great deal of confidence, quite a lot of confidence, not very much confidence or none at all?" We consider "Justice System/Courts" (V114), "The Government" (V115) and "Parliament" (V117). We quantify reported confidence levels in an ordered manner such that 1 represents the lowest and 4 corresponds to the highest level of confidence for each institution. Given that three trust measures are ordered and categorical, we run polychoric principal factor analysis (PPFA) on these trust indicators in order to create a robust political trust variable on state institutions. PPFA analysis indicates a one-factor solution and allows us to construct a continuous index for trust in main state institutions. Factor loadings for our observed variables (i.e. trust in parliament, government, and the judiciary) are very high, $0.805,0.821$, and 0.694 respectively, indicating a successful creation of a latent variable of political trust. Furthermore, standard Cronbach's alpha for our latent variable is 0.796, which is well above the conventional boundaries for scale construction. For robustness check, we conduct separate PPFA for each country, we find one-factor solution for each country with similarly very high levels of factor loadings. These findings imply that structure of the data is similar across countries. Empirical results of PPFA are provided in "Appendix 4".

To ensure comparability with the WVS trust measures, we rescale our continuous trust variable such that it ranges between 1 and 4 ( 4 indicating the highest level of trust). The aggregate-level range of our trust variable runs from 2.98 in Singapore to 1.77 in Peru. The most trusting countries in our sample are Philippines, India, Sweden, Malaysia, and Singapore. The least trusting countries on the other hand are Ukraine, Romania, Tunisia, Slovenia, and Peru. There are noticeable differences within geographic regions, which further ensures diversity within and across regions.

\subsection{Independent Variables}

Our major explanatory variable is the level of education. To get the best sense of the original WVS categorization, we have recoded the WVS categorization into four categories. ${ }^{3}$ The lowest category refers to those who have no formal diploma at all $(10.67 \%$ of the entire sample). The second category has those respondents with primary school diplomas (27.72\% of the sample). The third category contains those with secondary school diplomas (44.18\%). Finally, the highest category consists of those with university-level degrees and higher $(17.43 \%)$.

To explore the multiple interactive and conditional effects of education on political trust, we take into account three interactive competing mechanisms through which education has a potential impact on political trust and use them as our supporting explanatory variables. First, we include the effect of post-materialism into our analysis and check whether educated citizens with post-materialist values will have different trust judgments

\footnotetext{
3 There are some overlaps with regard to people's educational attainment and record (when we use degree completion as our main criterion) in the WVS's original 9-category education (such as category-4 referring to "Incomplete secondary school: technical/vocational type" and category-6 referring to "Incomplete secondary school: university-preparatory type"). We have focused on the completion of each degree (primary, secondary, and tertiary), treated incompletion of degrees with the completion of one lower degree (e.g.: hence treating categories 4 and 6 like that with primary school diplomas) and recoded the education variable accordingly so as to get the best possible inferences.
} 
(due to their critical stance toward political institutions) than those with similar levels of education yet with materialist values. We use the WVS question about post-materialism to check this effect.

Second, we investigate the enabling effect of education under the existence of meritocratic political institutions (or the lack thereof). We contend that highly educated citizens will have higher trust judgments should they believe that their states are meritocratic and that they (or similar citizens with high caliber) will have higher chances of partaking in political institutions (hence the name "enabling effect"). We make use of the V-Dem dataset's meritocracy variable ( $v 2$ stcritrecadm), which measures to what extent appointment decisions in the state administration are based on skills and merit, as opposed to personal and political connections (V-Dem Dataset 2017). ${ }^{4}$

Third, we explore the evaluative effect of education, in which education has a conditional conditioning effect on political trust in relation to political corruption. We maintain that educated citizens living in more clean societies will have higher trust judgments about state institutions, as opposed to those residing in corrupt nations. We utilize the V-Dem's political corruption variable ( $\left.v 2 x \_c o r r\right)$, which measures the pervasiveness of political corruption in three main branches of the state (which is also in line with our trust variable). ${ }^{5}$

For the sake of reliability, we check whether our meritocracy and political corruption variables are associated. Their pairwise correlation is -0.69 . However, there are countries with comparatively less meritocratic states yet with low levels of corruption (such as Cyprus) and countries with meritocratic governance with comparatively higher levels of corruption (such as Taiwan). This also confirms that differentiating the enabling and evaluative effects of education on political trust is an appropriate step to better understand the contextual, interactive effects of education. Moreover, we run a multicollinearity test with our full model (with all of our independent variables, only without the interaction terms) and find that there is not a problem of multicollinearity. The variance inflation factors (VIFs) of independent variables range between 1.03 and 8.91 with a mean VIF of 2.33 (3.04 and 8.91 for our meritocracy and political corruption variables). The VIFs do not exceed conventional boundary of 10 , indicating that our models are not prone to multicollinearity. "Appendix 5" presents VIFs and tolerance measures for our variables of interest.

Another issue that we should check is endogeneity. Although both of our political corruption and meritocracy variables are from the V-Dem dataset (i.e. based on expert evaluations), it is possible that these variables are endogenous to citizens' attitudes toward political institutions. When we run endogeneity tests (Hausman tests) in light of similarly scholarly works (cf. Anderson and Tverdova 2003; Hakhverdian and Mayne 2012) for our

\footnotetext{
${ }^{4}$ While the meritocracy variable perfectly captures our theoretical linkage of the enabling effect of education, the V-Dem dataset offers data on this variable for a more limited number of countries (for instance, 17 countries for our sample). There is not any systematic error in the V-Dem dataset to disregard countries regionally and/or socioeconomically. However, for a robustness check and for the sake of higher reliability, we also used an alternative variable in the same dataset, i.e. equal access index "v2xeg_eqaccess", which measures how equal access to power is and captures the de facto capabilities of citizens to participate, to serve in positions of political power, to put issues on the agenda, and to influence policymaking. Our substantive results do not change (results are available upon request). Hence, we stick to our meritocracy variable for the sake of validity since this variable better captures our theoretical claim.

5 Leading studies in the field such as Hakhverdian and Mayne (2012) utilize Transparency International's Corruption Perception Index (CPI) to measure the extent of corruption. We believe that V-Dem's political corruption variable better captures the extent of corruption in the major state institutions as it directly measures corruption in the legislative, executive, and judicial branches and goes beyond the perceptive aspects of the CPI. Hence, we believe that it is a more valid measure for our purposes.
} 
corruption and meritocracy variables, we find signs of endogeneity for both (less so for the meritocracy variable). Hence, we should underline once again that our findings are correlative in nature and that we do not claim any causality in our statistical results. As we focus on multiple correlative pathways through which education may alter levels of political trust in the world, delving into the causal relationships between political corruption, meritocracy and political trust is out of the scope of this research.

Lastly, for the sake of comparability, we standardize our post-materialism, meritocracy and political corruption measures such that they all range between 0 and 1 . This will help us juxtapose the substantive effects of each interactive mechanism.

\subsection{Control Variables}

Previous studies indicate a collection of individual-level factors besides level of education that predict political trust (Dalton 2005; Freitag and Bühlmann 2009; McLaren 2012; Hakhverdian and Mayne 2012; Zmerli 2012; Bauer and Fatke 2014; Van der Meer and Hakhverdian 2016). These include demographic and socioeconomic variables such as gender, age, and religiosity. It is open to debate whether age is a determining factor due to its life cycle or generational effect. For example, while Richardson et al. (2001) argue that older people are more likely to trust due to having more experience with political authorities (Bauer and Fatke 2014), Inglehart (1977, 1990, 2003) argues that the effect of age is a generational matter with those raised under more socio-economically secure decades being more likely to be more post-materialist and therefore trust less in government institutions. Nevertheless, there is a consensus over the issue that age needs to be controlled for in the examination of trust.

Moreover, we control for attitudinal and behavioral factors that are found to be positively associated with political trust, including interpersonal trust (Dalton 2004; Zmerli and Newton 2008; Hakhverdian and Mayne 2012; Zmerli 2012) and political factors such as ideological disposition along the left-right political spectrum and the incumbency effect (Miller and Listhaug 1999; Anderson and Tverdova 2003; Norris 2003; Zmerli 2012; Van der Meer and Hakhverdian 2016).

At the country-level, control variables include level of economic development as captured by log GDP per capita, unemployment rate, and Gallagher index for disproportionality (cf. Lijphart 1999; Mishler and Rose 2001; Norris 2003; Dalton 2004; Freitag and Bühlmann 2009; Hakhverdian and Mayne 2012; McLaren 2012; Zmerli 2012; Van der Meer and Hakhverdian 2016; Tormos 2019). To further capture the effects of changes in the quality of democratic governance, we also utilize the polyarchy variable from the V-Dem dataset. This variable measures the achievement of ideal electoral democracy conditions in the corresponding country. It ranges from 0 to 1 , in which higher values indicate more democratic conditions. We intentionally use a minimalistic index of democracy to prevent any multicollinearity with our other explanatory and control variables. Using a democracy score will help us explain the changes in political trust with regard to changes in the educational attainment in tandem with changing democratic conditions. This will show us whether citizens with the same level of education will have higher or lower trust in more democratic nations. Controlling for the level of democratic quality is also aimed to be a contribution to the literature, which usually studies countries as either single-case analysis or in regional analysis with no treatment of changing democratic conditions among countries. 


\subsection{Data Analysis}

We contend that education has conditional, interactive effects with micro- as well as macro-level variables, which cumulatively affect people's attitudes and trust orientations toward political institutions. The existence of potentially influential control variables both at the individual and country levels also calls for a multilevel framework. Individuals nested within national contexts can be influenced by these country-level correlates (Snijders and Bosker 1999; Steenbergen and Jones 2002). Multilevel treatment and analysis of political trust is gaining attention and popularity in recent years (Zmerli 2012; Hakhverdian and Mayne 2012). Variance components analysis for the empty model shows that while individual-level factors account for the most of the variance in political trust $(85.02 \%$ to be exact), country-level factors still account for an important portion, which should not be neglected (14.98\% based on intra-class correlations). The LR test result (with a Chi square of 8936.46) for the multilevel model also shows that the data at hand is nested in nature and ignoring contextual variance at the country level would lead us to miss out important explanations for political trust. Hence, our two-level, multi-level framework includes both micro- and macro-level variables to better understand the correlates of political trust.

In our general multilevel models, individual-level factors compose the level-1 model, while measures at the country level are included in the level- 2 model. We also have interaction terms for the education variable and our moderating variables (post-materialism, meritocracy and political corruption) so as to capture the conditional effects of education on political trust. ${ }^{6}$ In addition to models with all of the moderating variables (in their level terms), we also run separate models with each of the interaction terms in separate models so as to best delineate the particular effects of each of our moderating variables on education (and on political trust). Since we use standardized variables for post-materialism, meritocracy, and political corruption, we would also be able to compare the substantive effects of critical, enabling, and evaluative components of education on political trust.

Below, we illustrate the equation for the general model of political trust for individual $i$ in country $j$. Each $\alpha_{\mathrm{kj}}$ term represents the impact of a particular variable on a person's trust vested in political institutions such that,

$$
\begin{aligned}
& \text { Political trust } \mathrm{ij}_{\mathrm{ij}}=\alpha_{0 \mathrm{j}}+\alpha_{1 \mathrm{j}} \text { Education }_{\mathrm{ij}}+\alpha_{2 \mathrm{j}} \text { Gender }_{\mathrm{ij}}+\alpha_{3 \mathrm{j}} \text { Age }_{\mathrm{ij}}+\alpha_{4 \mathrm{j}} \text { Age } \text { squared }_{\mathrm{ij}}
\end{aligned}
$$

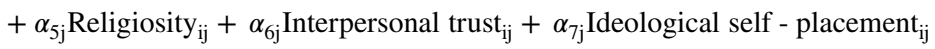

$$
\begin{aligned}
& +\alpha_{8 \mathrm{j}} \text { Support incumbent }_{\mathrm{ij}}+\alpha_{9 \mathrm{j}} \text { Post - Materialism index } \mathrm{ij}_{\mathrm{j}} \\
& +\alpha_{10 \mathrm{j}} \text { Education }_{\mathrm{ij}} * \text { Post - Materialism index } \mathrm{ij}_{\mathrm{ij}}+\alpha_{11 \mathrm{j}} \text { Education }_{\mathrm{ij}} * \text { Meritocracy }_{\mathrm{j}} \\
& +\alpha_{12 \mathrm{j}} \text { Education }_{\mathrm{ij}} * \text { Political corruption }_{\mathrm{j}}+e_{\mathrm{ij}} \text {. }
\end{aligned}
$$

The intercept of this equation, $\alpha_{0 \mathrm{j}}$, illustrates the average political trust in country $j$ and is modeled as a function of country-level factors in the level- 2 equation. Each $\beta$ term represents the effect of a particular country level variable on a person's level of political trust, and $\beta_{00}$ is the average intercept across countries. Hence,

\footnotetext{
6 Since the education variable is an individual-level variable and our meritocracy and corruption variables are at the country-level, their separate interactions yield another individual-level variable (for each individual $\mathrm{i}$ in country $\mathrm{j}$ ). Hence, these interaction terms are also added to the level-1 equation.
} 


$$
\begin{aligned}
\alpha_{0 \mathrm{j}}= & \beta_{00}+\beta_{01} \text { Economic development }_{\mathrm{j}}+\beta_{02} \text { Unemployment }_{\mathrm{j}} \\
& +\beta_{03} \text { Gallagher index of disproportionality }_{\mathrm{j}}+\beta_{04} \text { Polyarchy }_{\mathrm{j}} \\
& +\beta_{05} \text { Political corruption }_{\mathrm{j}}+\beta_{06} \text { Meritocracy }_{\mathrm{j}}+\mathrm{u}_{0 \mathrm{j}} .
\end{aligned}
$$

\section{Empirical Findings}

We begin our empirical analyses with exploring education's base effect with no interactions at all. This would be similar to treating education as a demographic control variable used in some scholarly research on political trust. According to the Model I in Table 1, education has a positive and significant relationship with political trust. To be more specific, ceteris paribus, the most educated are more inclined to vest higher levels of trust in political institutions than the least educated (by 0.0458 units to be exact). This is a valuable finding yet it does not tell us about how and through what mechanisms education can (and does) affect people's orientations toward political institutions. We will look at these mechanisms in further tests in our successive models.

Model II illustrates the empirical model with the inclusion of our control variables at the individual and country levels. Keeping the least educated as our reference category, it is clear that higher levels of education are correlated with increased levels of political trust even after controlling for potentially important variables at both levels.

Models III, IV, and V reveal how education interacts with our moderating variables (post-materialism, meritocracy, and political corruption respectively) and how these interactions may alter people's perceptions toward political institutions. Based on Model III, we test our first hypothesis, which indicates the "critical effect" of education. Empirical results show us that given an educational attainment level, every unit increase in post-materialism will lower average political trust by around 0.05 units. Given that our standardized postmaterialism index ranges between 0 and 1, this means that when two hypothetical people with the same level of education happen to have post-materialist values versus fully materialist orientations, the former on average would have lower political trust than the latter by 0.05 units. Substantively, given that our trust variable ranges between 1 and 4 , such difference between materialist and post-materialist citizens is not that salient. Hence, we find statistical support for our first hypothesis, but less support substantively.

The second conditional effect of education is about its "enabling effect" with meritocracy. Based on Model IV in Table 1, we test whether education's impact on political trust is moderated by meritocracy at the country level (Hypothesis 2). Empirical results show us that given an educational attainment level, people living in countries with more meritocratic political institutions would on average have higher levels of political trust than those living in less meritocratic countries. Statistical tests further reveal that it is the secondary school graduates and especially the university-degree holders, who show strong and statistically significant interaction effects between education and meritocracy. For university graduates (as compared to people with no diploma), meritocracy's interaction with education tend to increase people's political trust by 1.429 units $(0.687+0.742$ units). This is both a statistically and substantively important finding, which underlines the conditional effect of education with meritocracy. This means that citizens (especially those with higher educational attainment) living in more meritocratic states (such as Australia, Spain, Uruguay) would on average have more faith in political institutions than in less meritocratic states (such as Armenia, Peru, Romania) since they believe that educational attainment will 


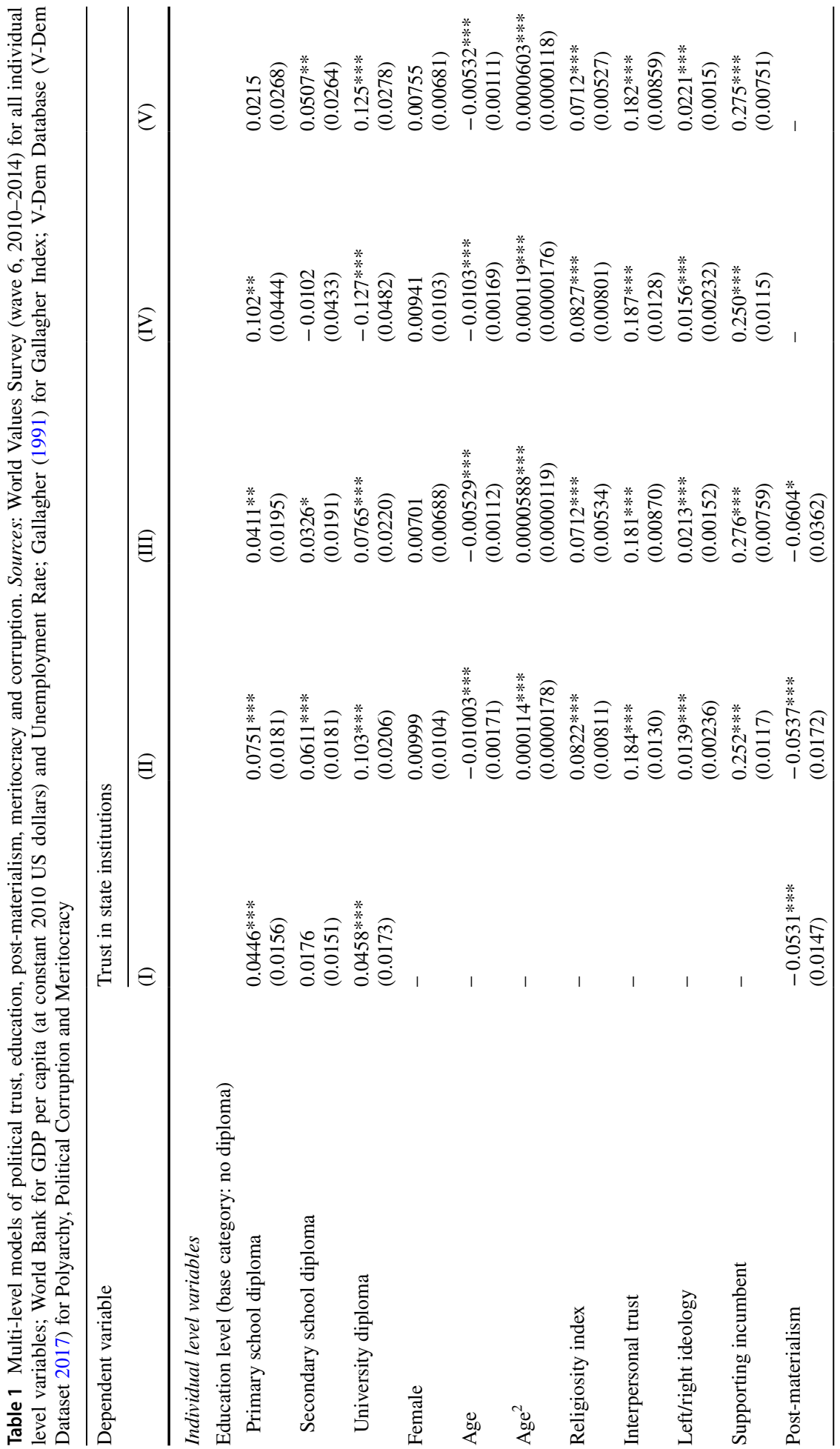




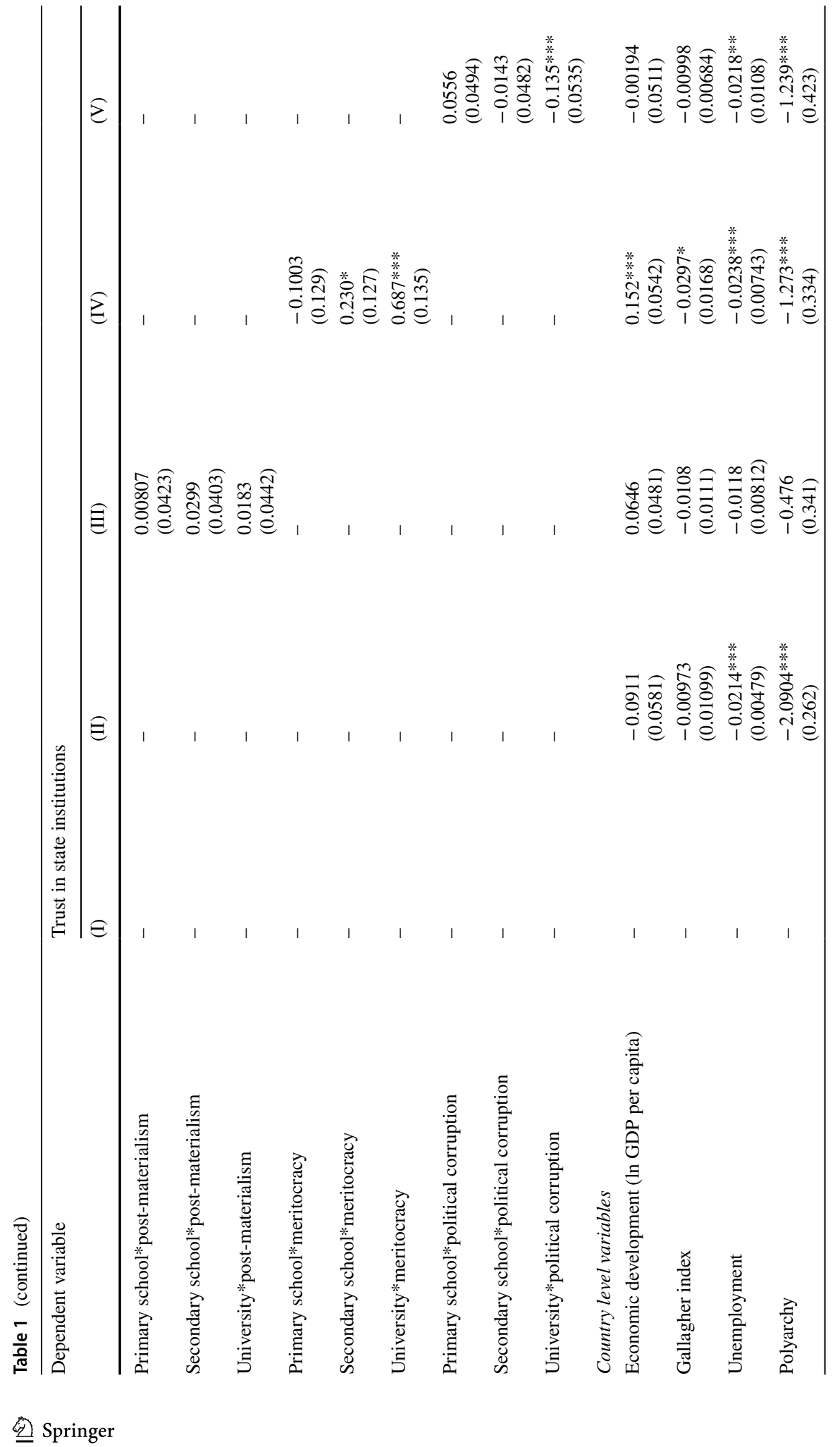




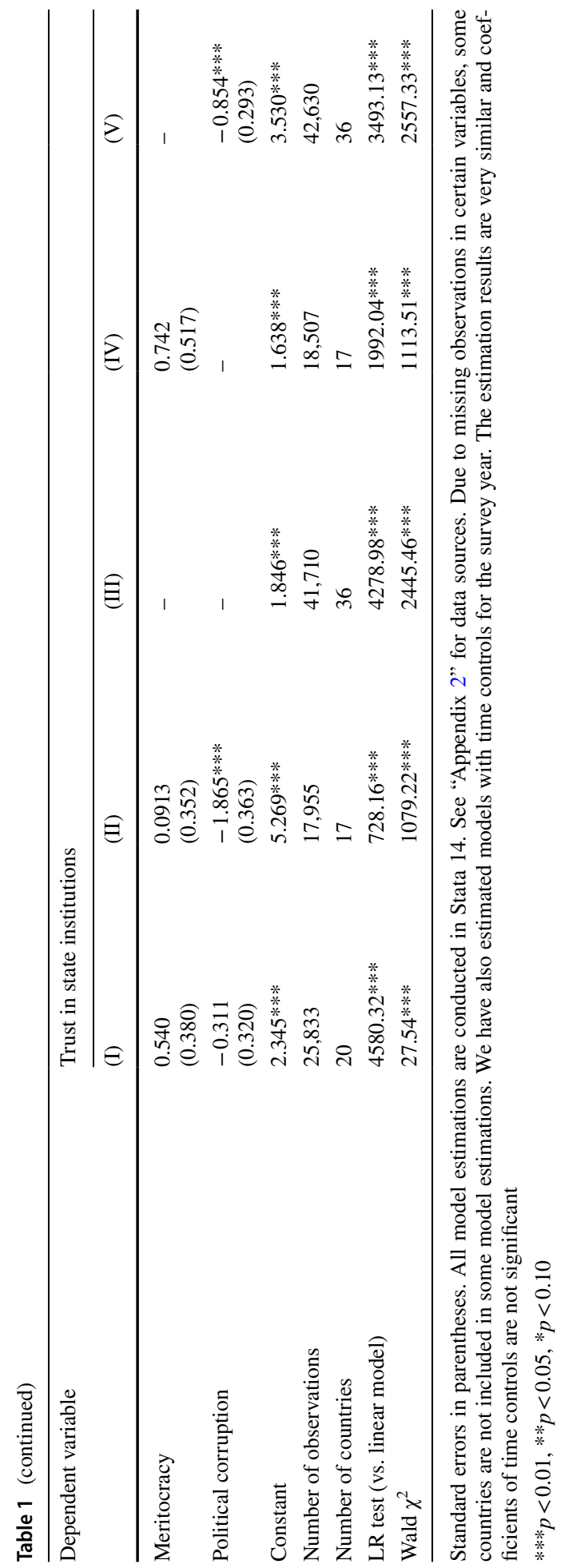


empower them and thus enable them to take part in political processes. Based on our findings, meritocracy has a strong moderating effect on education, which influences people's orientations toward political institutions. In short, we strongly confirm Hypothesis 2.

The third and final conditional effect of education is about its "evaluative effect" with political corruption. Based on Model V in Table 1, we test whether education's effect on political trust is moderated by political corruption at the macro level. Empirical results indicate that given an educational attainment level, citizens living in less corrupt societies would on average have higher levels of political trust than those living in more corrupt societies (recall that our political corruption variable ranges between 0 and 1, 1 indicating the highest level of corruption). Specifically, empirical tests show us that it is especially the university graduates (as compared to the reference category) who would statistically and substantively higher levels of political trust in less corrupt nations $(0.989$ units to be exact; i.e. $0.854+0.135$ units). This means that on average, educated citizens (as compared to the least educated) living in more clean states (such as Sweden, New Zealand, Germany, and Netherlands) would react more positively to the absence of corruption and tend to vest more trust in political institutions. Conversely, more educated citizens residing in countries with comparatively high levels of political corruption (such as Nigeria, Ukraine, Kyrgyzstan, and Pakistan) would be more inclined to be distrustful to political institutions than the less educated. Just in the case of meritocracy's moderating effect on education (and on political trust), it is again striking to see that the "evaluative effect" of education in linkage to political corruption is stronger in more educated citizens. It is especially the most educated citizens, who are influenced by the context-specific, moderating effects of corruption in the education-political trust nexus.

\section{Discussion of Empirical Findings}

Before we further delve into the multiple interactive pathways through which education affects political trust, it would be appropriate to discuss the substantive findings of our research based on other independent variables. Our empirical models show that some of our control variables have consistently strong impact on political trust. Accordingly, age has a U-shaped quadratic relationship with political trust, in which mid-aged citizens have lower trust in political institutions than the youngsters and the elderly. Furthermore, religiously devout citizens, those who have higher interpersonal trust, people on the right hand of the ideological spectrum, voters who support the incumbent political parties are expected to have a higher tendency to have more faith in political institutions. At the country level, unemployment lowers political trust. Moreover, disproportional political institutions tend to decrease political trust (while this effect is consistently negative, it is only significant in Model IV).

When used as a control variable, polyarchy variable diminishes trust in political institutions. This shows that, ceteris paribus, citizens in more democratic nations are less trusting of political institutions. In Model II, every increase in our polyarchy variable will decrease average political trust by 2.09 units. Given our polyarchy variable ranges between 0 and 1 (1 referring to the most democratic state), this means that people on average would approximately have 2 units less trust in political institutions in a perfectly democratic country than in a perfectly authoritarian country. To give a more illustrative example, a citizen with the same level of education would on average have 1 unit less political trust in a more 
democratic country with a polyarchy score of 0.90 (Germany, Australia) than in a less democratic country with a polyarchy score of 0.40 (Singapore, Thailand).

Turning back to the conditional effects of education on political trust, we have found that it has indeed critical, enabling, and evaluative aspects that are linked to its moderation by post-materialist values, meritocratic government, and political corruption. Education's interaction with post-materialism reveals that holding educational attainment constant, it is those citizens with more post-materialist values who have diminished levels of trust toward political institutions.

A comparison of substantive findings based on the standardized scores of post-materialism, meritocracy, and political corruption tell us that the enabling and evaluative effects of education are much stronger than the critical effect of education (though the latter has still some statistical significance). In other words, education's interaction with meritocracy and political corruption is found out to be much more salient than its moderation by postmaterialist values. Specifically, we find that the conditional effects of education with meritocracy and political corruption are particularly important and have huge impact on people's trust judgments about state institutions. Given any educational attainment level, when education's interactive effects are activated with the knowledge of a meritocratic state or of a corrupt one, this would have major substantive effects on citizens' faith in political institutions.

\section{Conclusion}

This study has delved into the issue of how education affects political trust. In doing so, it has been guided by the main arguments raised in the relevant literature. One of the main questions was whether education increases political trust among citizens by enabling them with new capacities and making them feel more invested in the system or whether, to the contrary, education leads to more critical citizens, thus diminishing the level of trust. In light of our findings, the answer to this question is, to quote Tilly and Goodin (2006): "It depends." It depends on the level of corruption in a country as well as on how meritocratic the country is. Post-material values are also important in order to activate the critical effects of education given both meritocracy and corruption are held constant in the countries under investigation. The study shows however that meritocracy and corruption as elements of the macro-level political system supersede the effect of post-materialism as an individual trait.

Our findings support Hakhverdian and Mayne's (2012) observations on the effects of corruption on the link between education and political trust. Yet, our study also illuminates some points that were left untouched in that study. For instance, based on Hakhverdian and Mayne (2012), one could speculate that the real difference between the split samples might have been another variable that would be doing the real work there. Such variables would include the level of democracy or the level of meritocracy or post-materialism within the subsamples. Yet, our study has shown that the level of electoral democracy does not bolster the political trust of educated people. On the contrary, democracy has a negative impact on the link between education and political trust. Also rather than splitting the sample from a threshold and using perception of corruption as a variable, we have chosen continuous variables and less subjective measures of corruption. Hence, our findings have shown that the negative impact of education on political trust in the presence of corruption holds even when more rigorous measures are made and the sample is extended. 
It should be noted that this study has its own limitations, which may be addressed by further research. The empirical analysis of the current study only analyzes correlations for variables of interest. Further studies should focus on providing empirical evidence for causal pathways between education, post-materialist values, meritocracy, political corruption and political trust. Specifically, relationships between meritocratic government, corruption and political trust and how this relationship varies with different levels of education can be further explored in future research based on methods such as experiments, focus groups and in-depth interviews. Moreover, this study utilizes cross-sectional surveys and it does not account for panel dimensions of political trust and explanatory variables. Empirical analysis of the above mentioned relationships by panel data frameworks can be further conducted by future research.

Another point worth mentioning is the nature of our sample. While the diversity of our sample ensures rich and fruitful research outcomes on the correlates of political trust, it is surely not without any drawbacks. Earlier research suggests that analyses based on value orientations throughout the globe can raise issues of comparability (Aleman and Woods 2016). These include empirical works, like ours, utilizing global datasets such as the WVS. When we probe our dataset in light of this illuminating line of research, we find that our political trust indicators and the resultant latent political trust measure are far from being perfect (we present our findings in "Appendix 6"). Measurement invariance analyses reveal that our whole sample has a root mean square error of approximation (RMSEA) of 0.107. While our factor analyses for individual countries reveal high factor loadings for all of our observed trust variables and a one-factor solution for all countries (see "Appendix 4") and although some researchers argue that it would be misleading to apply universal cutoff points for measure of goodness-of-fit in structural equation models without the knowledge of the nature and the size of samples (Chen et al. 2008), our RMSEA figure hints that there are certain issues of comparability for our political trust indicators (cf. MacCallum et al. 1996; Chen et al. 2008; Acock 2013; Aleman and Woods 2016). When we categorize our sample based on three criteria (democracy status, economic development level, and cultural groups across the globe-based on Welzel (2013) (see "Appendix 6"), we observe that certain subsamples have comparatively higher degree of comparability and goodness of fit, including partly-free countries (Freedom House democracy status), low-income and lower-middle income countries (World Bank economic development classification), and certain sub-groups of countries based on the Welzel's 10 cultural groups (Reformed Western, New Western, and Sub-Saharan African nations have the best fit). While we admit that our diverse sample and our measures in light of this sample are far from being perfect, we believe that utilizing such a global-scale, rich sample and conducting analyses based on this sample outweigh the drawbacks it brings about. As Mayne and Hakhverdian (2016) suggest, while researchers should offer in-depth, country-level research, the research on political trust still begs for more diverse analyses, which transcend the small, well-studied group of fully democratic countries. Our endeavor in this research should be taken in this light as it aims to enrich the existing literature on political trust.

Lastly, future research needs to shed more light on the relationship between democracy and political trust. Our finding that, ceteris paribus, citizens in more democratic countries hold more critical stance toward political institutions can be interpreted in two possible ways. First, as some scholars suggest, more democratic contexts create an increasingly sophisticated citizenry. While thinking that political institutions are essential for well-functioning of the state apparatuses, citizens in highly democratic countries also see them as a "necessary evil" and approach them with distrust (Warren 1999; Rosanvallon 2008; Della Porta 2010; Ignazi 2014). These scholars see distrusting citizens not as alarming but a part 
and parcel of healthy democracies. Alternatively, this finding may also suggest that citizens are more expressive about their ideas under more democratic settings. This means that people in more democratic contexts can more openly express their trust judgments than in less democratic ones (Rose 2007; Darden and Grzymala-Busse 2006). This may also bring about the divergence in trust judgments in linkage with changing democratic quality. All in all, how citizens' trust judgments toward political institutions are shaped based on different political and socioeconomic contexts offers an exciting future line of research. There are multiple pathways through which important political, social, and economic indicators can alter the level of political trust in democratic societies. Our research aims to contribute to our understanding about the correlates of political trust, which is a key element for the stability and legitimacy of political institutions.

\section{Appendix 1: List of countries included in the study}

\begin{tabular}{lcc}
\hline & Survey year & $\begin{array}{c}\text { Number of } \\
\text { participants }\end{array}$ \\
\hline Argentina & 2013 & 1030 \\
Armenia & 2011 & 1100 \\
Australia & 2012 & 1477 \\
Brazil & 2014 & 1486 \\
Chile & 2011 & 1000 \\
Colombia & 2012 & 1512 \\
Cyprus & 2011 & 1000 \\
Ecuador & 2013 & 1202 \\
Estonia & 2011 & 1533 \\
Georgia & 2014 & 1202 \\
Germany & 2013 & 2046 \\
Ghana & 2012 & 1552 \\
India & 2012 & 5659 \\
Japan & 2010 & 2443 \\
Kyrgyzstan & 2011 & 1500 \\
Lebanon & 2013 & 1200 \\
Malaysia & 2012 & 1300 \\
Mexico & 2012 & 2000 \\
Netherlands & 2012 & 1902 \\
New Zealand & 2011 & 841 \\
Nigeria & 2011 & 1759 \\
Pakistan & 2012 & 1200 \\
Peru & 2012 & 1210 \\
Philippines & 2012 & 1200 \\
Poland & 2012 & 966 \\
Romania & 2012 & 1072 \\
Singapore & 2012 & 3531 \\
Slovenia & 2011 & \\
South Africa & 2013 & \\
\hline & & \\
\hline
\end{tabular}




\begin{tabular}{llc}
\hline & Survey year & $\begin{array}{c}\text { Number of } \\
\text { participants }\end{array}$ \\
\hline South Korea & & 1200 \\
Spain & 2010 & 1189 \\
Sweden & 2011 & 1206 \\
Taiwan & 2011 & 1238 \\
Thailand & 2012 & 1200 \\
Trinidad and Tobago & 2013 & 999 \\
Tunisia & 2011 & 1205 \\
Turkey & 2013 & 1605 \\
Ukraine & 2011 & 1500 \\
United States & 2011 & 2232 \\
Uruguay & 2011 & 1000 \\
\hline
\end{tabular}

Sources: World Values Survey, Wave 6 (2010-2014). Countries selection is based on Freedom House "Freedom in the World" reports and Polity IV index (Polity IV Project 2019; Freedom House 2019)

\section{Appendix 2: Variable descriptions for empirical analyses}

Trust in state institutions

Education

Female

Age

Religiosity index

Interpersonal trust
This continuous variable is based on trust measures on judiciary/ courts, government and parliament (WVS survey items V114, V115, and V117 respectively in Wave 6). Polychoric principal factor analysis is employed to create a continuous trust variable, ranging between 1 and 4, 4 representing the highest

WVS asks respondents their highest level of education attained. We have created a 4-level, discrete variable. $1=$ No diploma; $2=$ Primary school diploma; $3=$ Secondary school diploma 4 $=$ University-level or higher level diploma

Respondent's gender (V240 in Wave 6). This variable is originally coded 1 for male and 2 for female. It is recoded such that 1 refers to female and 0 refers to male

Respondent's age (V242 in Wave 6)

We have used three variables in WVS to create religiosity variable. Related questions and variables in WVS are "How important is religion in your life?" (V9 in Wave 6), "How often do you attend religious services?" (V145 in Wave 6), and "Independently of whether you attend religious services or not, would you say you are religious person?" (V147 in Wave 6). We rescaled these variables so that higher values represent higher religiosity. We then performed PCA to create religiosity index, scaled between 1 and 4, 4 representing the highest level of religiosity

WVS asks respondents whether they think most people can be trusted or whether one needs to be very careful when dealing with people (V24 in Wave 6). Variable is coded as 1 for "most people can be trusted" and 2 for "need to be very careful". We recoded variable so that 0 represents non-trusting citizens and 1 trusting ones

Left-right ideological self-placement WVS asks respondents where they would place themselves in ideological spectrum, 1 being the most extreme leftist disposition and 10 being the most extreme right-wing disposition (V95 in Wave 6) 


\begin{tabular}{|c|c|}
\hline Supporting incumbent & $\begin{array}{l}\text { Based on WVS survey question asking which party respondents } \\
\text { would vote for if there were a national election tomorrow (V228 } \\
\text { in Wave 6), we have created an incumbency dummy variable. If } \\
\text { the respondent's answer includes the party (or parties) in power, } \\
\text { then the dummy gets value of } 1 \text {, else }\end{array}$ \\
\hline Post-materialism index & $\begin{array}{l}\text { This index is based on the WVS variable Y002 (in Wave } 6 \text { ). It is } \\
\text { originally scaled between } 1 \text { and } 3 \text {. We have rescaled this variable } \\
\text { to range between } 0 \text { and } 1.0 \text { representing a materialist person and } \\
1 \text { representing a post-materialist }\end{array}$ \\
\hline Logarithm of GDP Per capita & $\begin{array}{l}\text { Logarithm of GDP per capita (at constant } 2010 \text { US dollars). (World } \\
\text { Development Indicators) }\end{array}$ \\
\hline Gallagher index & $\begin{array}{l}\text { Measures relative disproportionality between votes and seats } \\
\text { received by political parties. This index ranges from } 0 \text { to } 100 \text {. The } \\
\text { larger the index the larger the disproportionality. (Gallagher 1991) }\end{array}$ \\
\hline Unemployment Rate (\%) & $\begin{array}{l}\text { Unemployment rate at country level (\% of total labor force). (World } \\
\text { Development Indicators) }\end{array}$ \\
\hline Polyarchy & $\begin{array}{l}\text { This variable is derived from electoral democracy index of V-Dem. } \\
\text { It measures the achievement of ideal electoral democracy condi- } \\
\text { tions in the corresponding country. It ranges from } 0 \text { to } 1 \text {. The } \\
\text { higher values indicate more democratic conditions. (V-Dem } \\
\text { Database) }\end{array}$ \\
\hline Political corruption & $\begin{array}{l}\text { This index ranges from } 0 \text { to } 1 \text {. The higher values indicate higher } \\
\text { corruption levels. (V-Dem Database v2x_corr variable) }\end{array}$ \\
\hline Meritocracy & $\begin{array}{l}\text { Measures the extent of meritocracy and skills in decisions for state } \\
\text { administration appointments. It originally ranges from } 0 \text { to } 4 \text {. } \\
\text { We have rescaled this variable to range between } 0 \text { and } 1 \text {. Higher } \\
\text { values indicate higher levels of meritocracy. (V-Dem Database } \\
\text { v2stcritrecadm variable) }\end{array}$ \\
\hline
\end{tabular}

Sources: World Values Survey (wave 6, 2010-2014) for all individual level variables; World Bank for GDP per capita (at constant 2010 US dollars) and Unemployment Rate; Gallagher (1991) for Gallagher Index; V-Dem Database (V-Dem Dataset 2017) for Polyarchy, Political Corruption and Meritocracy

\section{Appendix 3: Descriptive statistics of variables}

\begin{tabular}{lcllrr}
\hline & Mean & Maximum & Minimum & SD & N \\
\hline Individual level variables & & & & & \\
Trust in state institutions & 2.33 & 4 & 1 & 0.77 & 56,510 \\
Education & 2.68 & 4 & 1 & 0.88 & 60,072 \\
Female & 0.52 & 1 & 0 & 0.50 & 60,342 \\
Age & 43.26 & 99 & 16 & 17.02 & 60,285 \\
Religiosity index & 3.01 & 4 & 1 & 0.83 & 56,615 \\
Interpersonal trust & 0.24 & 1 & 0 & 0.43 & 58,945 \\
Left-right ideological self-Placement & 5.73 & 10 & 1 & 2.32 & 50,537 \\
Supporting incumbent & 0.31 & 1 & 0 & 0.46 & 60,388 \\
Post-materialism index & 0.39 & 1 & 0 & 0.31 & 57,988 \\
Country level variables & & & & & \\
Logarithm of GDP per capita & 9.24 & 10.88 & 6.83 & 1.17 & 40 \\
Gallagher index & 7.11 & 25.75 & 0.3 & 5.03 & 37 \\
\hline
\end{tabular}




\begin{tabular}{lccccc}
\hline & Mean & Maximum & Minimum & SD & N \\
\hline Unemployment rate (\%) & 7.64 & 24.6 & 0.7 & 5.04 & 40 \\
Polyarchy & 0.72 & 0.93 & 0.34 & 0.18 & 40 \\
Political corruption & 0.38 & 0.90 & 0.006 & 0.30 & 40 \\
Meritocracy & 0.30 & 0.72 & 0.091 & 0.19 & 20 \\
\hline
\end{tabular}

Sources: World Values Survey (wave 6, 2010-2014) for all individual level variables; World Bank for GDP per capita (at constant 2010 US dollars) and Unemployment Rate; Gallagher (1991) for Gallagher Index; V-Dem Database (V-Dem Dataset 2017) for Polyarchy, Political Corruption and Meritocracy

\section{Appendix 4: Eigenvalues and factor loadings from polychoric principal factor analysis}

\begin{tabular}{|c|c|c|c|c|c|c|c|}
\hline & \multirow[t]{2}{*}{$\mathrm{N}$} & \multicolumn{3}{|c|}{ Eigenvalues } & \multicolumn{3}{|c|}{ Factor loadings } \\
\hline & & Factor 1 & Factor 2 & Factor 3 & $\begin{array}{l}\text { Trust in } \\
\text { parliament }\end{array}$ & $\begin{array}{l}\text { Trust in } \\
\text { govern- } \\
\text { ment }\end{array}$ & $\begin{array}{l}\text { Trust in jus- } \\
\text { tice system }\end{array}$ \\
\hline All countries & 56,510 & 1.804 & -0.095 & -0.159 & 0.805 & 0.821 & 0.694 \\
\hline Argentina & 973 & 1.725 & -0.059 & -0.183 & 0.835 & 0.758 & 0.673 \\
\hline Armenia & 1008 & 2.032 & -0.053 & -0.116 & 0.890 & 0.892 & 0.666 \\
\hline Australia & 1424 & 1.724 & -0.064 & -0.167 & 0.811 & 0.837 & 0.604 \\
\hline Brazil & 1441 & 1.618 & -0.071 & -0.196 & 0.700 & 0.808 & 0.689 \\
\hline Chile & 964 & 1.783 & -0.090 & -0.169 & 0.824 & 0.753 & 0.731 \\
\hline Colombia & 1466 & 1.859 & -0.089 & -0.157 & 0.728 & 0.837 & 0.792 \\
\hline Cyprus & 966 & 1.627 & -0.102 & -0.176 & 0.778 & 0.778 & 0.644 \\
\hline Ecuador & 1199 & 1.402 & -0.126 & -0.191 & 0.722 & 0.699 & 0.626 \\
\hline Estonia & 1533 & 1.838 & -0.045 & -0.148 & 0.845 & 0.871 & 0.603 \\
\hline Georgia & 1062 & 2.096 & -0.032 & -0.114 & 0.887 & 0.915 & 0.686 \\
\hline Germany & 1928 & 2.003 & -0.013 & -0.065 & 0.947 & 0.946 & 0.458 \\
\hline Ghana & 1552 & 1.420 & -0.108 & -0.200 & 0.654 & 0.744 & 0.661 \\
\hline India & 3483 & 1.676 & -0.129 & -0.163 & 0.733 & 0.773 & 0.734 \\
\hline Japan & 2003 & 1.949 & -0.024 & -0.094 & 0.917 & 0.920 & 0.510 \\
\hline Kyrgyzstan & 1483 & 1.893 & -0.113 & -0.143 & 0.770 & 0.818 & 0.794 \\
\hline Lebanon & 917 & 1.124 & -0.144 & -0.194 & 0.573 & 0.624 & 0.636 \\
\hline Malaysia & 1298 & 1.953 & -0.088 & -0.141 & 0.732 & 0.848 & 0.835 \\
\hline Mexico & 1961 & 1.710 & -0.137 & -0.153 & 0.754 & 0.767 & 0.743 \\
\hline Netherlands & 1748 & 2.095 & -0.034 & -0.090 & 0.920 & 0.923 & 0.628 \\
\hline New Zealand & 731 & 1.954 & -0.059 & -0.129 & 0.876 & 0.872 & 0.653 \\
\hline Nigeria & 1759 & 1.760 & -0.090 & -0.169 & 0.776 & 0.821 & 0.695 \\
\hline Pakistan & 1139 & 1.119 & -0.049 & -0.238 & 0.642 & 0.706 & 0.456 \\
\hline Peru & 1182 & 1.901 & -0.121 & -0.138 & 0.802 & 0.806 & 0.778 \\
\hline Philippines & 1196 & 1.603 & -0.128 & -0.171 & 0.696 & 0.760 & 0.735 \\
\hline Poland & 845 & 1.859 & -0.022 & -0.157 & 0.829 & 0.882 & 0.627 \\
\hline Romania & 1377 & 1.911 & -0.023 & -0.126 & 0.878 & 0.901 & 0.571 \\
\hline Singapore & 1971 & 2.195 & -0.048 & -0.119 & 0.856 & 0.908 & 0.797 \\
\hline
\end{tabular}




\begin{tabular}{|c|c|c|c|c|c|c|c|}
\hline & \multirow[t]{2}{*}{$\mathrm{N}$} & \multicolumn{3}{|c|}{ Eigenvalues } & \multicolumn{3}{|c|}{ Factor loadings } \\
\hline & & Factor 1 & Factor 2 & Factor 3 & $\begin{array}{l}\text { Trust in } \\
\text { parliament }\end{array}$ & $\begin{array}{l}\text { Trust in } \\
\text { govern- } \\
\text { ment }\end{array}$ & $\begin{array}{l}\text { Trust in jus- } \\
\text { tice system }\end{array}$ \\
\hline Slovenia & 1002 & 1.977 & -0.046 & -0.119 & 0.886 & 0.894 & 0.626 \\
\hline South Africa & 3331 & 1.926 & -0.085 & -0.152 & 0.769 & 0.849 & 0.782 \\
\hline South Korea & 1193 & 1.876 & -0.026 & -0.172 & 0.755 & 0.873 & 0.736 \\
\hline Spain & 1115 & 1.554 & -0.082 & -0.197 & 0.789 & 0.717 & 0.645 \\
\hline Sweden & 1148 & 1.679 & -0.078 & -0.174 & 0.817 & 0.792 & 0.618 \\
\hline Taiwan & 1112 & 1.914 & -0.097 & -0.148 & 0.793 & 0.837 & 0.763 \\
\hline Thailand & 1087 & 1.668 & -0.081 & -0.172 & 0.809 & 0.800 & 0.610 \\
\hline Trinidad and Tobago & 870 & 1.916 & -0.057 & -0.133 & 0.867 & 0.873 & 0.633 \\
\hline Tunisia & 1055 & 1.588 & -0.025 & 0.181 & 0.804 & 0.839 & 0.486 \\
\hline Turkey & 1519 & 1.828 & -0.093 & -0.155 & 0.824 & 0.816 & 0.693 \\
\hline Ukraine & 1500 & 2.134 & -0.039 & -0.117 & 0.879 & 0.912 & 0.728 \\
\hline United States & 2152 & 1.884 & -0.025 & -0.160 & 0.818 & 0.881 & 0.661 \\
\hline Uruguay & 897 & 1.760 & -0.079 & -0.160 & 0.824 & 0.822 & 0.635 \\
\hline
\end{tabular}

Source: World Values Survey, Wave 6 (2010-2014)

\section{Appendix 5: Variance inflation factors (VIF) for variables}

\begin{tabular}{lcc}
\hline & VIF & $\begin{array}{l}\text { Tolerance } \\
(1 / \text { VIF })\end{array}$ \\
\hline Individual level variables & & \\
Education level & 1.21 & 0.82 \\
Female & 1.03 & 0.97 \\
Age & 1.16 & 0.86 \\
Religiosity index & 1.60 & 0.62 \\
Interpersonal trust & 1.11 & 0.90 \\
Left-right ideological self-placement & 1.09 & 0.91 \\
Supporting incumbent & 1.05 & 0.95 \\
Post-materialism index & 1.03 & 0.97 \\
Country level variables & & \\
Logarithm of GDP per capita & 4.41 & 0.23 \\
Gallagher index & 1.89 & 0.53 \\
Unemployment rate & 1.38 & 0.73 \\
Polyarchy & 3.67 & 0.27 \\
Political corruption & 8.91 & 0.11 \\
Meritocracy & 3.04 & 0.33 \\
\hline
\end{tabular}

Sources: World Values Survey (wave 6, 2010-2014) for all individual level variables; World Bank for GDP per capita (at constant 2010 US dollars) and Unemployment Rate; Gallagher (1991) for Gallagher Index; V-Dem Database (V-Dem Dataset 2017) for Polyarchy, Political Corruption and Meritocracy. Variance inflation factors are derived from linear multiple regression model of "Trust in State Institutions" on explanatory variables 


\section{Appendix 6: Measurement invariance analysis}

\begin{tabular}{|c|c|c|c|c|c|c|c|c|c|c|}
\hline & $\chi^{2}$ & $\mathrm{DF}$ & $\chi^{2} / \mathrm{DF}$ & $\mathrm{CFI}(\Delta \mathrm{CFI})$ & TLI & RMSEA & SRMR & $\mathrm{CD}$ & AIC & BIC \\
\hline \multicolumn{11}{|c|}{ All countries } \\
\hline $\begin{array}{l}\text { Configu- } \\
\text { rational } \\
\text { invari- } \\
\text { ance }\end{array}$ & $53,593.4 * * *$ & 120 & 446.6 & 1.000 & 1.000 & 0.000 & 0.000 & 0.795 & $366,500.6$ & $369,719.8$ \\
\hline $\begin{array}{l}\text { Metric } \\
\text { invari- } \\
\text { ance }\end{array}$ & $2025.2^{* * *}$ & 117 & 17.3 & $0.964(-0.036)$ & 0.963 & 0.107 & 0.146 & 0.769 & $368,291.9$ & $370,464.8$ \\
\hline $\begin{array}{l}\text { Scalar } \\
\text { invari- } \\
\text { ance }\end{array}$ & $19,403.7 * * *$ & 234 & 82.9 & $0.642(-0.322)$ & 0.816 & 0.241 & 0.278 & 0.795 & $385,436.4$ & $386,563.1$ \\
\hline \multicolumn{11}{|c|}{$\begin{array}{l}\text { Free countries (Argentina, Australia, Brazil, Chile, Taiwan, Cyprus, Estonia, Germany, Ghana, India, Japan, } \\
\text { South Korea, Netherlands, New Zealand, Peru, Poland, Romania, Slovenia, South Africa, Spain, Sweden, Trini- } \\
\text { dad and Tobago, United States, Uruguay) }\end{array}$} \\
\hline $\begin{array}{l}\text { Configu- } \\
\text { rational } \\
\text { invari- } \\
\text { ance }\end{array}$ & $32,819.5 * * *$ & 72 & 455.8 & 1.000 & 1.000 & 0.000 & 0.000 & 0.807 & $221,520.3$ & $223,347.6$ \\
\hline $\begin{array}{l}\text { Metric } \\
\text { invari- } \\
\text { ance }\end{array}$ & $1378.0 * * *$ & 69 & 19.9 & $0.960(-0.04)$ & 0.958 & 0.114 & 0.150 & 0.770 & $222,760.3$ & $224,003.9$ \\
\hline $\begin{array}{l}\text { Scalar } \\
\text { invari- } \\
\text { ance }\end{array}$ & $10,817.8^{* * *}$ & 138 & 78.4 & $0.674(-0.286)$ & 0.830 & 0.231 & 0.258 & 0.788 & $232,062.0$ & $232,721.9$ \\
\hline \multicolumn{11}{|c|}{$\begin{array}{l}\text { Partly free countries (Armenia, Colombia, Ecuador, Georgia, Kyrgyzstan, Lebanon, Malaysia, Mexico, Nigeria, } \\
\text { Pakistan, Philippines, Singapore, Thailand, Tunisia, Turkey, Ukraine) }\end{array}$} \\
\hline $\begin{array}{l}\text { Configu- } \\
\text { rational } \\
\text { invari- } \\
\text { ance }\end{array}$ & $20,773.9 * * *$ & 48 & 432.8 & 1.000 & 1.000 & 0.000 & 0.000 & 0.780 & $144,980.3$ & $146,129.7$ \\
\hline $\begin{array}{l}\text { Metric } \\
\text { invari- } \\
\text { ance }\end{array}$ & $529.9 * * *$ & 45 & 11.8 & $0.977(-0.023)$ & 0.975 & 0.089 & 0.105 & 0.770 & $145,420.3$ & $146,210.5$ \\
\hline $\begin{array}{l}\text { Scalar } \\
\text { invari- } \\
\text { ance }\end{array}$ & $7600.3^{* * *} *$ & 90 & 84.4 & $0.638(-0.339)$ & 0.807 & 0.249 & 0.262 & 0.803 & $152,400.6$ & $152,831.6$ \\
\hline \multicolumn{11}{|c|}{$\begin{array}{l}\text { Welzel Latin America (Argentina, Brazil, Chile, Colombia, Ecuador, Mexico, Peru, Trinidad and Tobago, Uru- } \\
\text { guay) }\end{array}$} \\
\hline $\begin{array}{l}\text { Configu- } \\
\text { rational } \\
\text { invari- } \\
\text { ance }\end{array}$ & $9152.3^{* * *} *$ & 27 & 338.9 & 1.000 & 1.000 & 0.000 & 0.000 & 0.789 & $75,670.5$ & $76,261.9$ \\
\hline $\begin{array}{l}\text { Metric } \\
\text { invari- } \\
\text { ance }\end{array}$ & $257.1 * * *$ & 24 & 10.7 & $0.974(-0.026)$ & 0.971 & 0.089 & 0.086 & 0.774 & $75,879.6$ & $76,295.8$ \\
\hline $\begin{array}{l}\text { Scalar } \\
\text { invari- } \\
\text { ance }\end{array}$ & $1517.8^{* * *}$ & 48 & 31.6 & $0.839(-0.135)$ & 0.909 & 0.159 & 0.108 & 0.781 & $77,092.3$ & $77,333.3$ \\
\hline
\end{tabular}




\begin{tabular}{|c|c|c|c|c|c|c|c|c|c|c|}
\hline & $\chi^{2}$ & $\mathrm{DF}$ & $\chi^{2} / \mathrm{DF}$ & CFI $(\Delta \mathrm{CFI})$ & TLI & RMSEA & SRMR & $\mathrm{CD}$ & AIC & BIC \\
\hline \multicolumn{11}{|c|}{ Welzel Orthodox East (Armenia, Georgia, Kyrgyzstan, Ukraine) } \\
\hline $\begin{array}{l}\text { Configu- } \\
\text { rational } \\
\text { invari- } \\
\text { ance }\end{array}$ & $6561.6^{* * * *}$ & 12 & 546.8 & 1.000 & 1.000 & 0.000 & 0.000 & 0.863 & $31,246.2$ & $31,481.2$ \\
\hline $\begin{array}{l}\text { Metric } \\
\text { invari- } \\
\text { ance }\end{array}$ & $76.8^{* * *}$ & 9 & 8.5 & $0.990(-0.01)$ & 0.986 & 0.077 & 0.060 & 0.860 & 31,305 & $31,481.3$ \\
\hline $\begin{array}{l}\text { Scalar } \\
\text { invari- } \\
\text { ance }\end{array}$ & $666.9^{* * *}$ & 18 & 37.1 & $0.901(-0.089)$ & 0.934 & 0.169 & 0.105 & 0.870 & $31,877.1$ & $31,994.6$ \\
\hline \multicolumn{11}{|c|}{ Welzel Returned West (Estonia, Poland, Romania, Slovenia) } \\
\hline $\begin{array}{l}\text { Configu- } \\
\text { rational } \\
\text { invari- } \\
\text { ance }\end{array}$ & $4904.2^{* * *}$ & 12 & 408.7 & 1.000 & 1.000 & 0.000 & 0.000 & 0.883 & $27,520.9$ & $27,753.2$ \\
\hline $\begin{array}{l}\text { Metric } \\
\text { invari- } \\
\text { ance }\end{array}$ & $127.3 * * *$ & 9 & 14.1 & $0.976(-0.024)$ & 0.968 & 0.106 & 0.169 & 0.863 & $27,630.3$ & $27,804.4$ \\
\hline $\begin{array}{l}\text { Scalar } \\
\text { invari- } \\
\text { ance }\end{array}$ & $953.6 * * *$ & 18 & 52.9 & $0.809(-0.167)$ & 0.873 & 0.211 & 0.272 & 0.884 & $28,438.5$ & $28,554.7$ \\
\hline \multicolumn{11}{|c|}{ Welzel New West (Australia, New Zealand, United States) } \\
\hline $\begin{array}{l}\text { Configu- } \\
\text { rational } \\
\text { invari- } \\
\text { ance }\end{array}$ & $4082.7 * * *$ & 9 & 453.7 & 1.000 & 1.000 & 0.000 & 0.000 & 0.847 & $24,775.7$ & $24,947.7$ \\
\hline $\begin{array}{l}\text { Metric } \\
\text { invari- } \\
\text { ance }\end{array}$ & $30.9 * * *$ & 6 & 5.1 & $0.994(-0.006)$ & 0.991 & 0.054 & 0.041 & 0.842 & $24,794.7$ & $24,928.4$ \\
\hline $\begin{array}{l}\text { Scalar } \\
\text { invari- } \\
\text { ance }\end{array}$ & $305.9 * * *$ & 12 & 25.5 & $0.928(-0.066)$ & 0.946 & 0.131 & 0.043 & 0.834 & $25,057.7$ & $25,153.2$ \\
\hline \multicolumn{11}{|c|}{ Welzel Old West (Cyprus, Spain) } \\
\hline $\begin{array}{l}\text { Configu- } \\
\text { rational } \\
\text { invari- } \\
\text { ance }\end{array}$ & $1462.2 * * *$ & 6 & 243.7 & 1.000 & 1.000 & 0.000 & 0.000 & 0.780 & $14,281.6$ & $14,383.1$ \\
\hline $\begin{array}{l}\text { Metric } \\
\text { invari- } \\
\text { ance }\end{array}$ & $53.7 * * *$ & 3 & 17.9 & $0.965(-0.035)$ & 0.930 & 0.128 & 0.115 & 0.755 & $14,329.3$ & $14,413.9$ \\
\hline $\begin{array}{l}\text { Scalar } \\
\text { invari- } \\
\text { ance }\end{array}$ & $352.3 * * *$ & 6 & 58.7 & $0.762(-0.203)$ & 0.762 & 0.236 & 0.143 & 0.754 & $14,621.9$ & $14,689.6$ \\
\hline \multicolumn{11}{|c|}{ Welzel Reformed West (Germany, Netherlands, Sweden) } \\
\hline $\begin{array}{l}\text { Configu- } \\
\text { rational } \\
\text { invari- } \\
\text { ance }\end{array}$ & $5014 * * *$ & 9 & 557.1 & 1.000 & 1.000 & 0.000 & 0.000 & 0.843 & $26,945.5$ & $27,120.5$ \\
\hline $\begin{array}{l}\text { Metric } \\
\text { invari- } \\
\text { ance }\end{array}$ & $16.3^{* * *}$ & 6 & 2.7 & $0.998(-0.002)$ & 0.997 & 0.033 & 0.032 & 0.843 & $26,949.8$ & $27,085.9$ \\
\hline $\begin{array}{l}\text { Scalar } \\
\text { invari- } \\
\text { ance }\end{array}$ & $307.5^{* * *} *$ & 12 & 25.6 & $0.941(-0.057)$ & 0.956 & 0.124 & 0.056 & 0.850 & $27,228.9$ & $27,326.2$ \\
\hline
\end{tabular}




\begin{tabular}{|c|c|c|c|c|c|c|c|c|c|c|}
\hline & $\chi^{2}$ & DF & $\chi^{2} / \mathrm{DF}$ & $\mathrm{CFI}(\Delta \mathrm{CFI})$ & TLI & RMSEA & SRMR & $\mathrm{CD}$ & AIC & BIC \\
\hline \multicolumn{11}{|c|}{ Welzel Sub-Saharan Africa (Ghana, Nigeria, South Africa) } \\
\hline $\begin{array}{l}\text { Configu- } \\
\text { rational } \\
\text { invari- } \\
\text { ance }\end{array}$ & $6175.8 * * *$ & 9 & 686.2 & 1.000 & 1.000 & 0.000 & 0.000 & 0.807 & $47,671.3$ & $47,854.9$ \\
\hline $\begin{array}{l}\text { Metric } \\
\text { invari- } \\
\text { ance }\end{array}$ & $69.0 * * *$ & 6 & 11.5 & $0.990(-0.01)$ & 0.985 & 0.069 & 0.092 & 0.812 & $47,728.3$ & $47,871.2$ \\
\hline $\begin{array}{l}\text { Scalar } \\
\text { invari- } \\
\text { ance }\end{array}$ & $276.7 * * *$ & 12 & 23.1 & $0.957(-0.033)$ & 0.968 & 0.100 & 0.102 & 0.815 & 47,924 & 48,026 \\
\hline \multicolumn{11}{|c|}{ Welzel Indic East (India, Malaysia, Pakistan, Philippines, Singapore, Thailand) } \\
\hline $\begin{array}{l}\text { Configu- } \\
\text { rational } \\
\text { invari- } \\
\text { ance }\end{array}$ & $9251.9 * * *$ & 18 & 513.9 & 1.000 & 1.000 & 0.000 & 0.000 & 0.778 & $68,872.7$ & 69,263 \\
\hline $\begin{array}{l}\text { Metric } \\
\text { invari- } \\
\text { ance }\end{array}$ & $238.6^{* * *}$ & 15 & 15.9 & $0.976(-0.024)$ & 0.971 & 0.094 & 0.116 & 0.745 & $69,081.4$ & $69,363.2$ \\
\hline $\begin{array}{l}\text { Scalar } \\
\text { invari- } \\
\text { ance }\end{array}$ & $1626.7 * * *$ & 30 & 54.2 & $0.827(-0.149)$ & 0.896 & 0.177 & 0.173 & 0.762 & $70,439.4$ & $70,612.9$ \\
\hline \multicolumn{11}{|c|}{ Welzel Sinic East (Japan, South Korea, Taiwan) } \\
\hline $\begin{array}{l}\text { Configu- } \\
\text { rational } \\
\text { invari- } \\
\text { ance }\end{array}$ & $4534.6^{* * * *}$ & 9 & 503.9 & 1.000 & 1.000 & 0.000 & 0.000 & 0.858 & 23,381 & 23,553 \\
\hline $\begin{array}{l}\text { Metric } \\
\text { invari- } \\
\text { ance }\end{array}$ & $172.6^{* * *}$ & 6 & 28.8 & $0.963(-0.037)$ & 0.945 & 0.139 & 0.116 & 0.845 & $23,541.7$ & $23,675.4$ \\
\hline $\begin{array}{l}\text { Scalar } \\
\text { invari- } \\
\text { ance }\end{array}$ & $1168.1 * * *$ & 12 & 97.3 & $0.745(-0.228)$ & 0.808 & 0.259 & 0.120 & 0.808 & $24,525.2$ & $24,620.6$ \\
\hline \multicolumn{11}{|c|}{ Welzel Islamic East (Tunisia, Turkey, Lebanon) } \\
\hline $\begin{array}{l}\text { Configu- } \\
\text { rational } \\
\text { invari- } \\
\text { ance }\end{array}$ & $2453.9 * * *$ & 9 & 272.6 & 1.000 & 1.000 & 0.000 & 0.000 & 0.745 & 26,135 & $26,301.3$ \\
\hline $\begin{array}{l}\text { Metric } \\
\text { invari- } \\
\text { ance }\end{array}$ & $118.3 * * *$ & 6 & 19.7 & $0.954(-0.046)$ & 0.931 & 0.127 & 0.132 & 0.745 & $26,241.4$ & $26,370.7$ \\
\hline $\begin{array}{l}\text { Scalar } \\
\text { invari- } \\
\text { ance }\end{array}$ & $1350.7 * * *$ & 12 & 112.5 & $0.452(-0.502)$ & 0.589 & 0.310 & 0.318 & 0.794 & $27,461.8$ & $27,554.1$ \\
\hline \multicolumn{11}{|c|}{$\begin{array}{l}\text { World Bank: low and low middle income (Kyrgyzstan, Armenia, Georgia, Ghana, India, Nigeria, Pakistan, Philip- } \\
\text { pines, Ukraine) }\end{array}$} \\
\hline $\begin{array}{l}\text { Configu- } \\
\text { rational } \\
\text { invari- } \\
\text { ance }\end{array}$ & $13,086.9 * * *$ & 27 & 484.7 & 1.000 & 1.000 & 0.000 & 0.000 & 0.783 & $98,587.1$ & $99,199.4$ \\
\hline
\end{tabular}




\begin{tabular}{|c|c|c|c|c|c|c|c|c|c|c|}
\hline & $\chi^{2}$ & $\mathrm{DF}$ & $\chi^{2} / \mathrm{DF}$ & CFI $(\Delta \mathrm{CFI})$ & TLI & RMSEA & SRMR & $\mathrm{CD}$ & AIC & BIC \\
\hline $\begin{array}{l}\text { Metric } \\
\text { invari- } \\
\text { ance }\end{array}$ & $256.3^{* * *}$ & 24 & 10.7 & $0.982(-0.018)$ & 0.980 & 0.078 & 0.100 & 0.774 & $98,795.4$ & $99,226.3$ \\
\hline $\begin{array}{l}\text { Scalar } \\
\text { invari- } \\
\text { ance }\end{array}$ & $2867.2^{* * * *}$ & 48 & 59.7 & $0.784(-0.198)$ & 0.879 & 0.193 & 0.175 & 0.792 & $101,358.3$ & $101,607.8$ \\
\hline \multicolumn{11}{|c|}{$\begin{array}{l}\text { World Bank: upper middle income (Argentina, Brazil, Chile, Colombia, Ecuador, Lebanon, Malaysia, Mexico, } \\
\text { Peru, Romania, South Africa, Thailand, Tunisia, Turkey, Uruguay) }\end{array}$} \\
\hline $\begin{array}{l}\text { Configu- } \\
\text { rational } \\
\text { invari- } \\
\text { ance }\end{array}$ & $18,207.9$ & 45 & 404.6 & 1.000 & 1.000 & 0.000 & 0.000 & 0.791 & $144,268.1$ & $145,339.5$ \\
\hline $\begin{array}{l}\text { Metric } \\
\text { invari- } \\
\text { ance }\end{array}$ & $589.6^{* * * *}$ & 42 & 14.0 & $0.970(-0.03)$ & 0.968 & 0.097 & 0.117 & 0.781 & $144,773.7$ & $145,511.8$ \\
\hline $\begin{array}{l}\text { Scalar } \\
\text { invari- } \\
\text { ance }\end{array}$ & $6656.3^{* * * *}$ & 84 & 79.2 & $0.638(-0.332)$ & 0.806 & 0.238 & 0.254 & 0.805 & $150,756.5$ & $151,161.2$ \\
\hline \multicolumn{11}{|c|}{$\begin{array}{l}\text { World Bank: high income (Australia, Cyprus, Estonia, Germany, Japan, Netherlands, New Zealand, Poland, } \\
\text { Singapore, Slovenia, South Korea, Spain, Sweden, Taiwan, Trinidad and Tobago, United States) }\end{array}$} \\
\hline $\begin{array}{l}\text { Configu- } \\
\text { rational } \\
\text { invari- } \\
\text { ance }\end{array}$ & $22,298.6^{* * *}$ & 48 & 464.5 & 1.000 & 1.000 & 0.000 & 0.000 & 0.835 & $123,645.4$ & $124,794.9$ \\
\hline $\begin{array}{l}\text { Metric } \\
\text { invari- } \\
\text { ance }\end{array}$ & $521.9 * * *$ & 45 & 11.6 & $0.979(-0.021)$ & 0.977 & 0.088 & 0.112 & 0.811 & $124,077.3$ & $124,867.7$ \\
\hline $\begin{array}{l}\text { Scalar } \\
\text { invari- } \\
\text { ance }\end{array}$ & $6715.2 * * *$ & 90 & 74.6 & $0.702(-0.272)$ & 0.841 & 0.233 & 0.215 & 0.835 & $130,180.6$ & $130,611.7$ \\
\hline
\end{tabular}

Structural equation modeling (SEM) framework is employed for multi-group factor analysis. STATA procedures described by MacDonald (2016) are used for estimation of models for different invariance models. Sources: World Values Survey (wave 6, 2010-2014). Free and Partly free statuses of countries are based on Polity IV and Freedom House classifications (Polity IV Project 2019; Freedom House 2019). Cultural group classifications are based on Welzel (2013). Income group classification of countries is based on the World Bank categorizations (WB, 2020)

$\chi^{2}$ Chi square, $D F$ degrees of freedom, $C F I$ comparative fit index, TLI Tucker-Lewis index, RMSEA Root mean squared error of approximation, $S R M R$ standardized root mean square residual, $C D$ coefficient of determination, AIC Akaike's information criterion, BIC Bayesian information criterion

$* * * p$ value 0.000

\section{References}

Acock, A. C. (2013). Discovering structural equation modeling using Stata (Rev. ed.). College Station, TX: Stata Press.

Aleman, J., \& Woods, D. (2016). Value orientations from the world values survey: How comparable are they cross-nationally? Comparative Political Studies, 49(8), 1039-1067.

Almond, G., \& Verba, S. (1963). The civic culture. Princeton: Princeton University Press.

Anderson, C. J. (1998). Parties, party systems, and satisfaction with democratic performance in the new Europe. Political Studies, 46, 572-588. 
Anderson, C. J., \& Singer, M. M. (2008). The sensitive left and the impervious right: Multilevel models and the politics of inequality, ideology, and legitimacy in Europe. Comparative Political Studies, 41(4/5), 564-599.

Anderson, C. J., \& Tverdova, Y. V. (2003). Corruption, political allegiances, and attitudes toward government in contemporary democracies. American Journal of Political Science, 47(1), 91-109.

Bauer, P., \& Fatke, M. (2014). Direct democracy and political trust: Enhancing trust, initiating distrustor both? Swiss Political Science Review., 20(1), 49-69.

Bouckaert, G., \& Van de Walle, S. (2013). Comparing measures of citizen trust and user satisfaction as indicators of 'good governance': Difficulties in linking trust and satisfaction indicators. International Review of Administrative Sciences, 69, 329-343.

Chang, E. C. C., \& Chu, Y. (2006). Corruption and trust: Exceptionalism in Asian democracies? Journal of Politics, 68(2), 259-271.

Chen, F., Curran, P., Bollen, K., Kirby, J., \& Paxton, P. (2008). An empirical evaluation of the use of fixed cutoff points in RMSEA test statistic in structural equation models. Sociological Methods and Research, 36(4), 462-494.

Dalton, R. J. (2004). Democratic challenges, democratic choices: The erosion of political support in advanced industrial democracies. Oxford: Oxford University Press.

Dalton, R. J. (2005). The social transformation of trust in government. International Review of Sociology, 15(1), 133-154.

Darden, K., \& Grzymala-Busse, A. (2006). The great divide: Literacy, nationalism, and the communist collapse. World Politics, 59(1), 83-115.

Davis, J. A. (1996). Review essay of value change in global perspective. Public Opinion Quarterly, 60(Summer), 322-331.

Della Porta, D. (2010). Democracy and distrust. Perspectives on Politics, 8(3), 890-892.

Duch, R. M., \& Taylor, M. A. (1993). Postmaterialism and the economic condition. American Journal of Political Science, 37, 747-779.

Freedom House. (2019). Freedom in the world statistics. Available at https://freedomhouse.org/content/ freedom-world-data-and-resources.

Freitag, M., \& Bühlmann, M. (2009). Crafting trust: The role of political institutions in a comparative perspective. Comparative Political Studies, 42(12), 1537-1566.

Gallagher, M. (1991). Proportionality, disproportionality and electoral systems. Electoral Studies, 10(1), 33-51.

Hakhverdian, A., \& Mayne, Q. (2012). Institutional trust, education, and corruption: A micro-macro interactive approach. The Journal of Politics, 74(3), 739-750.

Hendriks, F. (2009). Contextualizing the Dutch drop in political trust: Connecting underlying factors. International Review of Administrative Sciences, 75(3), 473-491.

Hooghe, M., Dassonneville, R., \& Marien, S. (2015). The impact of education on the development of political trust: Results from a five-year panel study among late adolescents and young adults in Belgium. Political Studies, 63(1), 123-141.

Hooghe, M., \& Marien, S. (2013). A comparative analysis of the relation between political trust and forms of political participation in Europe. European Societies, 15(1), 131-152.

Ignazi, P. (2014). Power and the (Il)legitimacy of political parties: An unavoidable paradox of contemporary democracy? Party Politics, 20(2), 160-169.

Inglehart, R. (1971). The silent revolution in Europe: intergenerational change in post-industrial societies. American Political Science Review, 65, 991-1017.

Inglehart, R. (1977). The silent revolution: Changing values and political styles among western publics. Princeton: Princeton University Press.

Inglehart, R. (1990). Culture shift in advanced industrial society. Princeton: Princeton University Press.

Inglehart, R. (1997). Modernization and post-modernization: Cultural, economic, and political change in 43 societies. Princeton: Princeton University Press.

Inglehart, R. (2003). Post-modernization erodes respect for authority, but increases support for democracy. In P. Norris (Ed.), Critical citizens: Global support for democratic government (pp. 103-122). Oxford: Oxford University Press.

Jiang, J., \& Yang, D. L. (2016). Lying or believing? Measuring preference falsification from political purge in China. Comparative Political Studies, 49(5), 600-634.

Kelleher, C. A., \& Wolak, Jennifer. (2007). Explaining public confidence in the branches of state government. Political Research Quarterly, 60(4), 707-721.

Kuran, T. (1997). Private truths, public lies: The social consequences of preference falsification. Cambridge: Harvard University Press. 
Levi, M., \& Stoker, L. (2000). political trust and trustworthiness. Annual Review of Political Science, 3, 475-507.

Lijphart, A. (1999). Patterns of democracy: Government forms and performance in thirty-six countries. New Haven CT: Yale University Press.

MacCallum, R. C., Browne, M. W., \& Sugawara, H. M. (1996). Power analysis and determination of sample size for covariance structure modeling. Psychological Methods, 1(2), 130-149.

MacDonald, K. (2016). Group comparisons in structural equation models: Testing measurement invariance. The Stata Blog: Not Elsewhere Classified. http://blog.stata.com/2016/08/23/group-comparison s-in-structural-equation-models-testingmeasurement-invariance/.

Marien, S. (2011). Measuring political trust across time and space. In M. Hooghe \& S. Zmerli (Eds.), Political trust, why context matters (pp. 13-46). Colchester: ECPR Press.

Mayne, Q., \& Hakhverdian, A. (2016). Education, socialization, and political trust. In S. Zmerli \& T. van der Meer (Eds.), Handbook on political trust. Cheltenham: Edward Elgar Publishing.

McLaren, L. M. (2012). The cultural divide in Europe: Migration, multiculturalism, and political trust. World Politics, 64(2), 199-241.

Milbrath, L. (1966). Political participation. How and why do people get involved in politics?. Chicago: Rand McNally.

Miller, A. H., \& Listhaug, O. (1990). Political parties and confidence in government: A comparison of Norway, Sweden, and the United States. British Journal of Political Science, 29, 357-386.

Miller, A. H., \& Listhaug, O. (1999). Political performance and institutional trust. In P. Norris (Ed.), Critical citizens: Global support for democratic governance (pp. 204-216). Oxford: Oxford University Press.

Mishler, W., \& Rose, R. (2001). What are the origins of political trust? Testing institutional and cultural theories in post-communist societies. Comparative Political Studies, 34(1), 30-62.

Norris, P. (2003). Critical citizens: Global support for democratic governance. Oxford: Oxford University Press.

Polity IV Project. (2019). Available at http://www.systemicpeace.org/polityproject.html.

Richardson, L., Houston, D., \& Hadjiharalambous, C. (2001). Public confidence in the leaders of American Governmental Institutions. In J. Hibbing \& E. Theiss-Morse (Eds.), What is it about government that Americans dislike? (pp. 83-97). Cambridge: Cambridge University Press.

Rosanvallon, Pierre. (2008). Counter-democracy: Politics in an age of distrust. Cambridge: Cambridge University Press.

Rose, R. (2007). Perspectives on political behavior in time and space. In R. J. Dalton \& H.-D. Klingemann (Eds.), Oxford handbook of political behavior (pp. 283-301). Oxford: Oxford University Press.

Scheidegger, R., \& Staerkle, C. (2011). Political trust and distrust in Switzerland: A normative analysis. Swiss Political Science Review, 17(2), 164-187.

Seligson, M. A. (2002). The impact of corruption on regime legitimacy: A Comparative study of four Latin American countries. Journal of Politics, 64(2), 408-433.

Snijders, T. A. B., \& Bosker, R. J. (1999). Multilevel analysis: An introduction to basic and advanced multilevel modeling. Thousand Oaks, CA: Sage Publications.

Steenbergen, M. R., \& Jones, B. S. (2002). Modeling multilevel data structures. American Journal of Political Science, 46(1), 218-237.

Stokes, D. (1962). Popular evaluations of government: An empirical assessment. In H. Cleveland \& H. D. Lasswell (Eds.), Ethics and bigness: Scientific, academic, religious, political, and military (pp. 61-72). New York: Harper.

The World Bank (WB). (2020). World Bank country and lending groups. Available at: https://datahelpde sk.worldbank.org/knowledgebase/articles/906519-world-bank-country-and-lending-groups.

Tilly, Charles, \& Goodin, R. E. (2006). It Depends. In R. E. Goodin \& C. Tilly (Eds.), The Oxford handbook of contextual political analysis (pp. 3-32). New York: Oxford University Press.

Tormos, R. (2019). Measuring personal economic hardship and its impact on political trust during the great recession. Social Indicators Research, 144(3), 1209-1232.

Turper, S., \& Aarts, K. (2017). Political trust and sophistication: Taking measurement seriously. Social Indicators Research, 130(1), 415-434.

Van der Meer, T., \& Hakhverdian, A. (2016). Political trust as the evaluation of process and performance: A cross-national study of 42 European countries. Political Studies, published online first, pp. 1-22.

Van Elsas, E. (2015). Political trust as a rational attitude: A comparison of the nature of political trust across different levels of education. Political Studies, 63, 1158-1178.

V-Dem Dataset. (2017). Coppedge, Michael, John Gerring, Staffan I. Lindberg, Svend-Erik Skaaning, Jan Teorell, David Altman, Michael Bernhard, M. Steven Fish, Adam Glynn, Allen Hicken, Carl Henrik Knutsen, Anna Lührmann, Kyle L. Marquardt, Kelly McMann, Valeriya Mechkova, Pamela Paxton, 
Daniel Pemstein, Laura Saxer, Brigitte Seim, Rachel Sigman, and Jeffrey Staton. Available at https:// www.v-dem.net/en/reference/version-7-may-2017/.

Warren, M. (1999). Democracy and trust. Cambridge: Cambridge University Press.

Wedeen, L. (1999). Ambiguities of domination: Politics, rhetoric, and symbols in contemporary Syria. Chicago: University of Chicago Press.

Welzel, C. (2013). Freedom rising: Human empowerment and the quest for emancipation. New York, NY: Cambridge University Press.

Zmerli, S. (2012). Social structure and political trust in Europe. In O. W. Gabriel \& S. Keil (Eds.), Society and democracy in Europe (pp. 111-138). London: Routledge.

Zmerli, S., \& Newton, K. (2008). Social trust and attitudes toward democracy. Public Opinion Quarterly, 72(4), 706-724.

Publisher's Note Springer Nature remains neutral with regard to jurisdictional claims in published maps and institutional affiliations. 